\title{
The Role of Ideological and Political Education in College Students' Political Socialization and Its Improvement Countermeasures - Based on the Relationship Between Ideological and Political Education and Political Socialization
}

\author{
Wen Qi \\ School of Public Administration, Sichuan University
}

\begin{abstract}
Political socialization is an aspect of socialization, and its goal is to cultivate sound, rational and qualified political people. With the continuous development of society, college students, as social citizens, gradually have the opportunity to change from management object to management subject in the trend of political socialization. In addition, College students are also the driving force of social development and the hope of making the whole country rich and strong. Therefore, making college students have enough political literacy and whether they are highly socialized will affect the development level of the whole society. At present, ideological and political education has been gradually popularized in universities, and the level of ideological and political education affects the results of college students' political socialization. It is particularly important to constantly improve and improve the contents, objectives and methods of ideological and political education so as to promote the political socialization of college students. This thesis will study the ideological and political education in colleges and universities from many aspects and analyze its role and value in the political socialization of college students one by one.
\end{abstract}

Keywords: Political socialization, Ideological and political education, College student.

\section{The Meaning of Political Socialization}

Political socialization refers to the active process in which members of society learn political knowledge and skills through various channels and form and change their own political culture. Political socialization is also the process of inheriting and developing specific political culture from generation to generation ${ }^{1}$. There are two main subjects in the process of political socialization, one is the state or the relevant institutions representing the will of the state, and the other is the citizen groups or individual citizens. In general, the concept of political socialization classifies these two types of subjects. The concept of the former mainly refers to a process of inculcating citizens' consciousness and cultivating political people. According to the concept of the latter, political socialization is a process in which citizens identify, choose, internalize political ideas and master corresponding political skills.

Secondly, from the perspective of political life, political socialization is a process of education and probation. It is the education or influence of various social members on social culture. It has gone through certain political organizations or social organizations. To systematically impart certain political thoughts and cultures, as well as related values, behavioral norms and other political contents and knowledge systems to social members, so that the existing political system can be maintained. On the other hand, political socialization is a subjective dynamic process of individuals, which is not only a

Li Yuanshu. Political socialization: meaning, characteristics and functions [J]. Political Science Research, 1998(2):19. kind of indoctrination and teaching from outside, but also the process of people participating in political practice. Social members can achieve political socialization by learning political knowledge and actively participating in political practice. In the process of individual social members receiving political culture education, their own political literacy and political skills have been improved. They can further improve their political personality.

\section{The Status Quo of College Students' Political Socialization}

\subsection{Political Cognition}

Political cognition is the perception, impression and cognitive judgment of political subjects on cognitive objects (such as political figures, political events and political activities, etc.), that is, the understanding and cognition of various political phenomena ${ }^{2}$. In the process of college students' political socialization, because college students are located in universities with specific geographical location, their political cognition mainly comes from the education of college students and universities.

For college students, colleges and universities are a place where political culture and political thoughts are instilled, trained and educated, and an important channel for most students' political socialization. In the education of colleges

\footnotetext{
${ }^{2}$ Wang Puqu. Basis of Political Science [M]. Beijing: Peking University
} Press, 2005:262,237,238 
and universities with moral education as the core goal, it is also one of the main educational goals to help college students shape good political personality and firm correct political direction. However, in the process of transforming higher education from elite to mass, the political socialization of college students will inevitably become empty. As far as education methods are concerned, the existing colleges and universities generally adopt large classes, which are mainly one-way indoctrination and simple preaching. It is undeniable that students can get a lot of political information in this process, but they lack internalization. It is impossible to shape one's own sound political personality through this thin political information. At the same time, colleges and universities are also schools after all, and their semi-closed academic places do not have rich social practice environment ${ }^{3}$. Political socialization without corresponding political behavior training is imperfect, which easily leads to idealization, one-sidedness and simplification of college students in the process of political socialization.

In a word, for politics, the cognition of college students is basically correct, but there are still vague and superficial places, and the cognitive state is ideal and one-sided.

\subsection{Political Participation}

The so-called political participation refers to the behavior of ordinary citizens participating in public political life by legal means based on their individual rights and aiming at influencing political decisions. As builders and successors of socialist cause, orderly political participation of college students is the proper meaning of socialist democratic politics ${ }^{4}$.

College students' political participation mainly means that after learning, they have a general understanding of the domestic political situation, and then participate in political life through some methods and have a certain political influence. In fact, most college students hold a positive attitude towards this, and their channels of political participation are more diversified. For example, many colleges and universities are actively developing party members in their schools. In recent years, more and more college students are eager to join the Communist Party of China (CPC). They are strict with themselves, learn from examples, and strive to shape themselves into excellent Communist Party members. In addition, daily student work or community activities can also make college students understand current political events at home and abroad. But several times, there are still some college students' political apathy, which is mainly manifested as being inactive, unconcerned and not participating in political activities.

\subsection{Political Emotion}

\footnotetext{
${ }^{3}$ Pan wanying. research on cultivating college students' socialist core values from the perspective of political socialization $[\mathrm{J}]$. ideological and theoretical education guide, 2018, (6):85-88.

${ }^{4}$ Chen Ying, Jiang Shanshan. Problems and Countermeasures of Political Socialization of Contemporary College Students [J]. Journal of Jilin Radio and TV University, 2008(1):106.
}

Political emotion refers to a kind of inner experience and feelings of political subjects to cognitive objects (political organizations, political systems, political behaviors, political events or political figures, etc.) on the basis of political cognition. "The formation of political emotion is basically a spontaneous process," so the tendency of college students' political emotion is determined by their $\operatorname{mood}^{5}$.

At present, most of the college students are "post-90s" and "post-90s". They have quick thinking, more flamboyant personality and rich feelings. They are generally wise and frivolous, mature but blind, rational and restless. Under the new situation, due to the influence of accepting the belief education, contemporary college students have firm political beliefs and strong sense of hardship. It is the most politically enthusiastic and politically sensitive group. It is not difficult to find that the vast majority of college students are very concerned about political hotspots and loyal to the party, the country and the people. However, influenced by their own age and experience, some college students' political feelings are relatively unstable, and their political enthusiasm is easy to fade. From the whole process of individual development, college students are in the process from youth to maturity, and their political emotions are changeable, lacking coherence and prone to fluctuation. At the same time, college students are not deeply involved in the world, are not mature in political rationality, and have weak theoretical knowledge base and relatively weak political screening ability, so they are prone to paranoia and extremes in political choice. And then indifferent to political activities, resulting in political apathy.

\section{Ideological and Political Education in Colleges and Universities}

\subsection{Problems in Ideological and Political Education in Colleges and Universities}

3.1.1 The intensity and intensity of ideological and political education is relatively low

The focus of university education has shifted to the development of the national economy. In order to develop the economy and adapt to the streamlined and effective education methods, universities began to implement the strategy of reducing teachers and students, in which the political and ideological education departments were seriously affected. This phenomenon made a department only have one ideological and political education cadre, or some teachers with multiple roles appeared. Teachers' education is under great pressure, and at the same time they are not valued and understood by people, which is undoubtedly a double blow to ideological and political educators. At the same time, universities have relatively high requirements for ideological and political educators, and many people with excellent abilities can be competent for other departments, so personnel changes will occur, which leads to the instability of

\footnotetext{
${ }^{5}$ Wang Puqu. Basis of Political Science [M]. Beijing: Peking University Press, 2005:262,237,238.
} 
ideological and political education departments or colleges in universities. Some universities also regard the ideological and political education department as an excessive post for teachers who are about to retire. The disadvantages of doing so are obvious, such as teachers' old thinking, lack of innovative thinking, and declining educational motivation in the late years. This arrangement is not conducive to the long-term development of ideological and political education in colleges and universities, nor to the study of students.

\subsubsection{The focus of ideological and political education shifts}

Under the influence of modern education system, the focus of ideological and political education in China has shifted, mainly from the power department to the functional department. On the one hand, this change will make the ideological and political education in colleges and universities vaguer, on the other hand, it will further lower the status of ideological and political education in colleges and universities. Its own weight is not as good as most professional courses, it has not received enough attention, and this influence is undoubtedly worse for itself. Therefore, the shift of the center of gravity not only hit the teachers' educational enthusiasm in the ideological and political education department, but also made the level and quality of ideological and political education for college students decline.

3.1.3 The ideological and political education mode is too formalism and too old.

Because the focus of ideological and political education is on education, education is mainly on economic development at present. Under such circumstances, on the one hand, ideological education in colleges and universities will not be valued by students, mainly because students do not pay enough attention to ideological and political education courses and are unwilling to actively explore and learn relevant knowledge, on the other hand, they will not be valued by teachers. This is mainly manifested in the marginalization and non-core of the knowledge taught by some teachers of ideological and political courses in the classroom. In this situation, ideological and political education in colleges and universities tends to formalism, with vague content and old form. If this way continues, the ideological and political education course in universities will become a superficial effort of formalism, lacking in inner, Students can't learn the real thing either.

\section{The Relationship Between Ideological and Political Education and Political Socialization of College Students}

\subsection{Comparison Between Ideological and Political Education and Political Socialization}

Comparing the connotation of the two, ideological and political education is to use certain ideological and theoretical knowledge to train the educated purposefully, so as to make it meet the social requirement of having political ideas. To be precise, ideological and political education is the influence form and dissemination mode of political socialization, which has a certain theoretical basis, but its goal has never changed. Comparing the two from the aspects of educational methods and contents, the ideological and political education in colleges and universities is influenced by the traditional educational model of colleges and universities, which is often limited to the unilateral teaching of theoretical knowledge in the classroom. Besides the above, the political socialization path of college students can also obtain political information through other ways to conduct self-learning and self-education. In general, we can think that ideological and political education pays attention to the result of education, while political socialization pays attention to the whole process. Compared with the former, the latter is broader and less targeted.

\subsection{The Inner Relationship Between Ideological and Political Education and Political Socialization of Contemporary College Students}

Political socialization is mainly a process of transmitting political consciousness, which can be understood as a process in which some institutions with the responsibility of educating political socialization transmit relevant political information in a planned, organized and targeted way by various methods, so that the educated can form systematic political thinking and political behavior patterns. And let them accept the current political system, political values and corresponding political norms, so as to gain political knowledge, establish political beliefs and cultivate political emotions, and realize the unity of political thinking and political behavior. In short, political socialization is a process in which members of society cultivate their established political consciousness through learning, from "natural person" to "political person" 6 . Ideological and political education refers to "the practice of ideological, moral and psychological comprehensive education with political and ideological education as the core and focus, which is carried out by a certain class or political group in order to achieve its political goals and tasks"[7] $]^{7}$. It can be seen that spreading political theory and ideological and political values is the core task of ideological and political education, which enables the educated to form political beliefs, values and norms of political behavior. To sum up, there is inherent consistency between ideological and political education and college students' political socialization, which is mainly manifested in the following aspects:

\subsubsection{Consistency of functions}

College students' political socialization emphasizes that social education embodies the will of the ruling class and serves the ruling class. The leader of ideological and political education is the ruling class.

${ }^{6}$ Tian Chao. The value and role of ideological and political education in the socialization of college students [J]. Journal of Weinan Teachers College, 2014,29(12):74-77.

${ }^{7}$ Liu Hongtao, Li Guangcai. The function of ideological and political education in college students' political socialization 


\subsubsection{Consistency of educational probation content}

Both of them represent the fundamental interests of the ruling class. The content of political socialization involves related political information, such as political thoughts, political ideas, and norms of political behavior. The content of ideological and political education is the will of the ruling class of the country, involving political thoughts, moral norms, political views and other political contents.

\subsubsection{Consistency of objectives}

The goal of both is to train the "political people" who are sound and qualified.

\section{The Role and Value of Ideological and Political Education in the Political Socialization of College Students}

The internal relationship between ideological and political education and college students' political socialization determines that it plays an important role in college students' political socialization, which is embodied in guiding the choice of political information, leading the incentive role of internalization and externalization of culture, and promoting the generation of political personality.

\subsection{Guiding Role of Political Information}

In the information age of Internet, everyone has abundant information. If the task of ideological and political education is only to transmit some political knowledge, it will undoubtedly be difficult to offset the challenge brought by the massive information to college students. The key to eliminating useless political information is to cultivate college students' scientific thinking methods and correct political value orientation. Only in this way, College students can install the "filter" of information psychologically, instead of relying on the limited political knowledge instilled from outside to fight against the "offensive" of complicated information. Therefore, colleges and universities should attach great importance to the education of historical materialism and materialist dialectics, so as to enable college students to establish materialist dialectical Marxist political views. Only by training scientific thinking mode and instilling necessary political common sense can we give full play to the guiding role of ideological and political education in political information, and enable college students to extract effective information from massive information and consciously resist the erosion of non-Marxist ideological trend.

\subsection{Leading the Motivation of Internalization and Externalization of Political Culture}

Cultivating college students' recognition of leading political culture is an important goal of college students' political socialization. Due to the lack of practical experience, ideological and political education needs to play an incentive role, so as to make the leading culture internalized in the hearts of college students and externalized in practice. This process needs to complete four changes: first, from "instillation" to "infiltration", to play the function of campus culture; The second is to form a joint force of social education from "single type" to "compound type"; The third is to broaden the field of practical education from "plane type" to "three-dimensional type"; Fourth, from "traditional" to "modern", seize the commanding heights of online education. The transformation from "indoctrination" to "infiltration" means that the way of college students' political socialization changes from simple indoctrination and preaching to entertainment activities and campus culture.

\subsection{The Promotion of the Generation of Political Personality}

Political socialization is a closely connected process of four stages: the choice of political information, the identification of leading culture, the externalization of behavioral norms and the generation of political personality. The generation of political personality is the last and most critical stage of political socialization. Long-term and stability are two characteristics of political personality. Therefore, it is necessary to improve the system of ideological and political education. It is necessary to carry out repeated education for college students whose political personality is formed, and to keep enough patience for college students who are in the forming state, and to innovate education methods to guide them. Only in this way can ideological and political education play a maximum role in generating political personality.

\section{Countermeasures to Improve the Current Situation of Ideological and Political Education in Colleges and Universities}

\subsection{Guiding the Socialization Environment of Universities}

Strengthening the key role of ideological and political education in college students' socialization.

University campus is the main place for college students to study and live, and it takes a long time, and four years is not a number, let alone the yearning of youth, which occupies a very important position in the whole life, so the quality of university life and education directly affects the mental outlook and ideological and political accomplishment of college students. From another point of view, universities should constantly beautify the campus environment, create a good campus atmosphere, improve the campus culture atmosphere, and build basic facilities on campus, so that students' learning enthusiasm and initiative can be improved through these measures.

\subsection{Deepen the Ideological and Political Education in Universities}

Among all the courses in universities, the courses related to ideology and politics (mainly including "ideological education", "recent courses", "Ma Yuan" and "Mao Gai") are 
also important compulsory courses. The key to improving the teaching level and quality of ideological and political courses is to increase research efforts in classroom content, which can be started from the following aspects: The first aspect is to increase the leading role of ideological and political education, highlight the characteristics of classroom education, let students quickly enter the educational scene of relevant knowledge, and be able to empathize with each other, so as to exert a subtle influence and study deeply. On the other hand, it is necessary to broaden students' ideological and political education and improve the teaching content. This requires that ideological and political education in colleges and universities should not only be implemented in classrooms and textbooks, but also pay attention to after-school educational means, such as the development of related activities and the publicity of related information. The third aspect is to pay attention to the effectiveness and practicability of classroom content, and the content taught by teachers should be to the point, and it should not be out of touch with the times. For example, the Chinese dream put forward by General Secretary Xi Jinping and the socialist core values in the new era, which are popular in the society at present, can be deeply explained by teachers, and it is best to ask teachers to explain to students the current political content and related thoughts that keep pace with the times.

\subsection{Explore New and Correct Teaching Methods to Improve the Level of Education}

The teaching method of ideological and political course plays an important role in the process of ideological and political education, and scientific methods can improve the effectiveness and practicability of ideological and political education. In the implementation of education, we should have insight into the development and changes of the times, learn to forge ahead, and explore new ideological and political education ideas and methods from the current new policy situation. So as to better improve the quality and efficiency of ideological and political education. Under the influence of today's society, ideological and political educators should constantly study and think, innovate their thinking, not only absorb the original educational experience and improve it, but also pay attention to the new educational development situation and combine the ideological and political education with the socialization of college students. In this way, both sides can promote each other. In addition, the ideological and political education departments in colleges and universities should also play a reasonable role in coordination, so that the teachers of ideological and political education and the educated students can communicate in time, reflect the development opinions, sum up the shortcomings, learn from each other's strengths, and jointly promote the development of ideological and political education in universities.

\section{Conclusion}

If college students want to become qualified political people, they must actively accept political culture through passive acceptance at first, and finally actively participate in the process of political socialization. The relationship between ideological and political education and college students' political socialization is closely linked, so universities should keep pace with the times and innovate ideas to face the reform of political education. Enabling students to actively participate in the process of political socialization is of great significance to the sustainable development of China's political culture.

In order to realize the political socialization of contemporary college students, it is necessary to correctly understand the relationship between ideological and political education in colleges and universities and political socialization of contemporary college students, and to effectively use ideological and political education to promote the realization of students' political socialization and help students achieve better development.

To sum up, ideological and political education in colleges and universities is an important way to standardize college students' social behavior and the main means to guide college students to establish a correct value system. It is hoped that through the elaboration of the article, the ideological and political educators in colleges and universities can recognize the important role of ideological and political education in the socialization development of college students.

\section{References}

[1] Yan Jirong. Political socialization: the study and dissemination of political culture $[N]$. Study Times, 2005-06-20.

[2] Huang Rongsheng. Youth studies [M]. Chengdu: Sichuan People's Publishing House, 2009.

[3] Qingdao University of Technology Research Group. Political socialization and ideological and political education in colleges and universities during the transition period [J]. Hebei Academic Journal, 2006, 26(1): 67-72.

[4] Tian Chao. The value and role of ideological and political education in the socialization of college students [J]. Journal of Weinan Teachers College, 2014, 29(12): 74-77.

[5] Liu Hongtao, Li Guangcai. The function of ideological and political education in college students' political socialization [J]. Lanzhou Academic Journal, 2010(S1): 146-148.

[6] Wang Puqu. Political Science Foundation [M]. Beijing: Peking University Press, 2005.

[7] Liang Huakui. Political socialization and Red Cultural Symbols in Lenin Period [J]. Kesism and Reality, 2017

[8] Mao Shoulong. Political sociology: the political and social foundation of democratic system [M]. Changchun: Jilin Publishing Group Co., Ltd., 2007.

[9] Cui Meina, Zhang Ping. Research on college students' practice of socialist core values-based on the perspective of political socialization [J]. Journal of Jiangxi Normal University (Philosophy and Social Sciences Edition), 2016, 49(06): 28-35.

[10] Pan Wanying. Research on cultivating college students' socialist core values from the perspective of political 
socialization [J]. Ideological and Theoretical Education Guide, 2018, (6): 85-88.

[11] Zhang Baojun. 90-year-old college students' psychological characteristics and countermeasures [J]. Ideological and Theoretical Education Guide, 2010(04): 111-114. 